\title{
Universitetsbibliotekets logo 100 år
}

På forsiden af Magasin troner Det Kongelige Biblioteks velkendte logo; den opslaede bog under kongekronen, der tilsammen danner initialerne 'KB'. Men også Universitetsbiblioteket har et smukt logo (som brugtes af Danmarks Natur-og Lagevidenskabelige Bibliotek indtil fusionen i 2005 med Det Kongelige Bibliotek), og det er designet af en af vore helt store logomagere, Knud V. Engelhardt, hvis livsverk er optaget i Kulturkanonen.

afbibliotekskonsulent Torsten Schlichtkrull, Det Kongelige Bibliotek

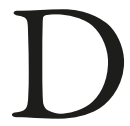
en 21. april 1914 skrev overbibliotekaren ved Universitetsbiblioteket to næsten enslydende breve, ${ }^{1}$ som han indledte sådan:

"Medens de allerfleste af vore større Institutioner raader over et eget Seglmærke, har Universitetsbiblioteket indtil nu savnet et saadant, og da der ikke kan være Tvivl om, at Seglet i repræsentativ Henseende spiller en væsentlig Rolle, anmodede jeg for længere Tid siden Hr. Arkitekt K. Engelhardt om at tegne nogle Udkast, som jeg kunde vælge imellem.”

Brevene blev sendt til Konsistorium og til Det Classenske Fideicommis' direktion og mundede ud i hhv. en anmodning om at måtte bruge af bibliotekets midler til seglet og en anmodning om støtte til samme.

Konsistorium skulle spørges; det var overbibliotekarens foresatte, og anskaffelse af et logo lå ikke inden for overbibliotekarens kompetence. Det Classenske Fideicommis blev spurgt, fordi de ydede væsentlige tilskud til Universitetsbiblioteket. Det havde det gjort siden 1867, hvor hovedparten af Det Classenske Bibliotek var blevet indlemmet i Universitetsbiblioteket og det samlede bibliotek videreført under navnet Universitetsbiblioteket og det dermed forenede Classenske Bibliotek.

Grundlæggeren af Det Classenske Bibliotek ${ }^{2}$ var Johan Frederik Classen (1725-92), som var den reelle grundlægger af Frederiksværk; han efterlod sig ingen arvinger, og ved sin død ejede han, foruden nogle ejendomme i København, hovedparten af den nuværende Halsnæs Kommune inklusive kanonstøberi og krudtværk samt to godser på Falster: Corselitze og Carlsfeldt. I alt vurderet til 1 million rigsdaler, som han testamenterede til en fond, Det Classenske Fideicommis. I testamentet bestemte han særskilt, at hans bibliotek skulle gøres offentligt tilgængeligt. Den 13 år yngre bror, Peder Hersleb Classen (17381825), stod i forreste række i virkeliggørelsen af storebroderens testamente og var i mange år direktør for Fideicommisset. Biblioteket blev et hjertebarn for ham, og han bekostede biblioteksbygningen i Amaliegade 38 af egen lomme. 


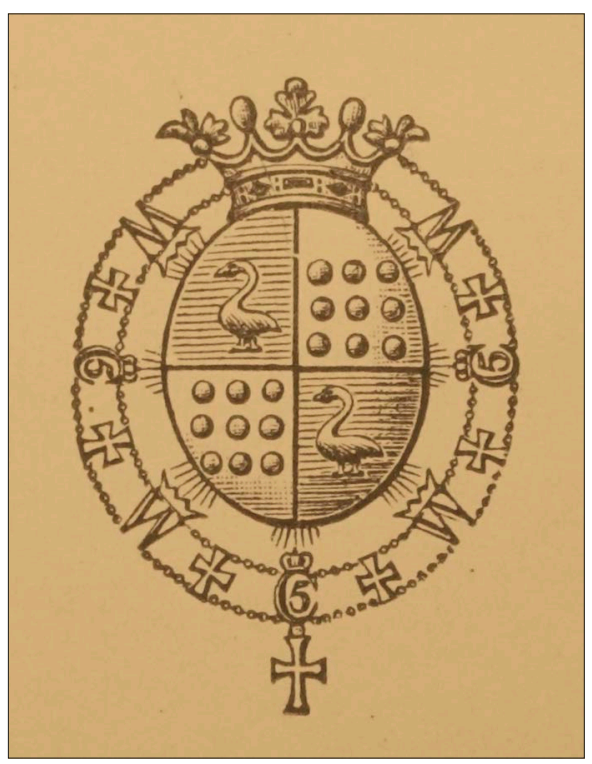

Ill. 1. Generalmajor Classens våben.

Classens våbenskjold var senest fra 1786 delt i fire felter, øverst til venstre en svane og ni kanonkugler til højre, nederst kanonkugler til venstre og svane til højre (ill. 1). ${ }^{3}$ Af lakseglene på Classens breve til sin agent, Jørgen Koustrup fremgår det, at han skiftede segl på et tidspunkt mellem den 3. og den 17. maj 1786. ${ }^{4}$ Hans første våben, det som bl.a. kan ses i Frederiksborg Slotskirke i forbindelse med hans udnævnelse til hvid ridder (sv.t. storkors af Dannebrog), består af kun ét felt, som har ni kanonkugler i sig - meget passende for en våbenfabrikant. Det er seglet med de fire felter, der blev anvendt som ejermærke på Det Classenske Biblioteks bøger. Anledningen til og tidspunktet for skiftet af segl får stå hen til en anden undersøgelse.

Vi skal tilbage til 1909, hvor Sofus Larsen (1855-1938) blev overbibliotekar ved Universitetsbiblioteket. Han afløste Sophus Birket Smith, som gennem en menneskealder havde arbejdet for at tilvejebringe en ny katalog for biblioteket. Dette arbejde fortsatte Sofus Larsen, samtidig med at han arbejdede ihærdigt for at markere Universitetsbibliotekets status som et bibliotek med gode og værdifulde samlinger. Et af resultaterne er bogen $E x$ Bibliotheca Universitatis Hafniensis, som kom i 1920. Bogens hovedindhold er en række lødige artikler om Universitetsbiblioteket og dets samlinger. Et andet resultat er udstillingen af Historiske og moderne Bogbind udstillede af Universitetsbiblioteket $i$ Forening med Bogbinderlauget og Teknologisk Institut i 1924. Larsen deltog også aktivt i den biblioteksdebat, der i de første årtier af 1900-tallet for en del var affødt af Universitetsbibliotekets manglende styrke på de naturvidenskabelige og medicinske fagområder.

Anskaffelsen af et logo skal ses som et led i, hvad man i dag vil kalde markedsføringen af biblioteket (udtrykket ville givetvis ligge Sofus Larsen fjernt). Ordet logo brugtes heller ikke på den tid. Man talte skiftevis om mærke, segl, sigil eller seglmærke.

K nud V. Engelhardt (18821931), der benævnte sig selv arkitekt og bogtrykker, var pioner inden for dansk design, og hans aktiviteter spændte over hele designspektret: Et hus på Skagen, bazarbygningen Trommesalen, kilometersten til de danske landeveje, hvor hans forslag ikke blev antaget, men dog i store træk anvendt, og han tegnede en sporvogn til Københavns Sporveje, som kørte med succes i mange år. Desuden vejnavneskilte, plakatsøjle og - ikke mindst - et utal af tryksager og mærker. Bogejermærker og logoer blev et speciale for Engelhardt, og han dyrkede genren med 


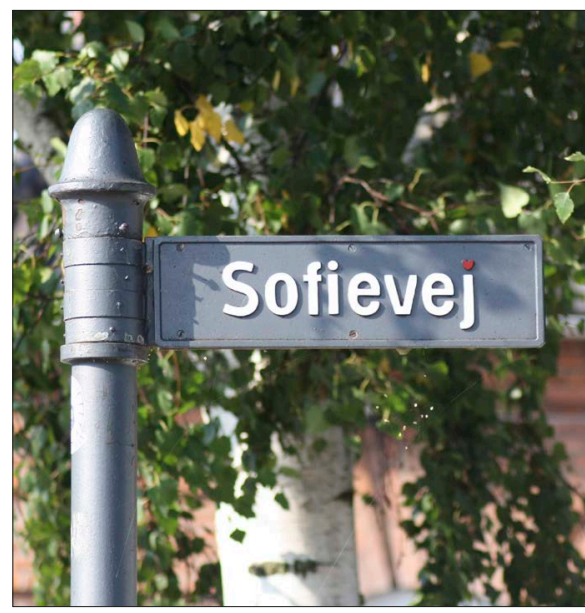

Ill. 2. Vejnavneskilt fra Gentofte med Engelhardts rode hjerte over ' $j$ ' $i$-vej.

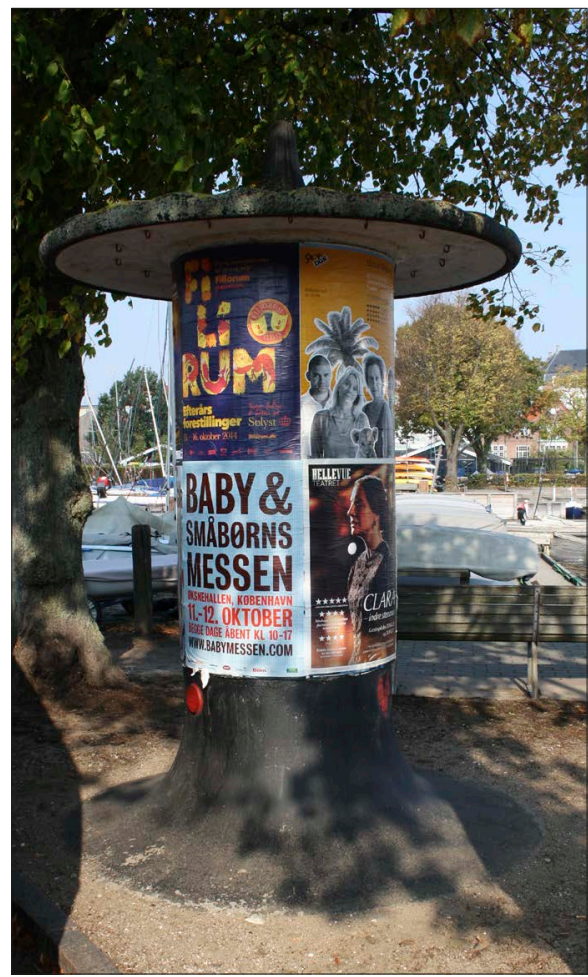

Ill. 3. Engelhardts plakatsøjle som den står på Hellerup Havn i oktober 2014. en virtuositet, der alene ville have gjort ham berømt. ${ }^{5}$

Engelhardts i dag bedst kendte arbejder er nok vejnavneskiltene og plakatsøjlerne i Gentofte Kommune (ill. 2 og 3). Plakatsøjlerne er fra 1923, ${ }^{6}$ og opgaven med vejnavneskiltene blev påbegyndt samme år. ${ }^{7}$ Vejnavneskiltene er let genkendelige med deres karakteristiske skrift - udviklet af Engelhardt selv - og ikke mindst hjertet over $j \mathrm{i}-v e j$. Hjertet var Engelhardts eget varemærke, og han placerede det i sine arbejder, hvis han kunne. ${ }^{8}$ Erik Ellegaard Frederiksen, selv et fyrtårn inden for dansk grafisk design, giver vejnavneskiltene disse ord med på vejen: "Der er ingen tvivl om, at Gentofte Kommunes skiltning er den mest rationelt gennemførte i landet. Den er smuk i sin enkelhed, tydelig og karakteristisk"." Gentofte Kommune har holdt fast ved vejnavneskilte og plakatsøjler, dog i en let moderniseret form. Der er 28 plakatsøjler, som ikke alle har det oprindelige design intakt, men kommunen arbejder aktivt for at det bliver nøjagtigt retableret på alle søjlerne. ${ }^{10}$

Der gik ikke lang tid fra Sofus Larsens tiltrædelse som overbibliotekar den 1. februar 1909 til den første samtale mellem ham og Engelhardt havde fundet sted, og de første skitser lå på Larsens bord i april 1909; de var meget løst tegnet (ill. 4). Sofus Larsen skrev, at han selv bad Engelhardt om at tegne nogle udkast. Ikke desto mindre er det er meget muligt, at den første kontakt skete på Engelhardts initiativ, thi Erik Ellegaard Frederiksen mere end antyder, at Engelhardt af egen drift opsøgte statsinstitutioner for at tilbyde dem sine ydelser, og han nævner specifikt Universitetsbibliotekets logo som et eksempel herpå. ${ }^{11}$ 


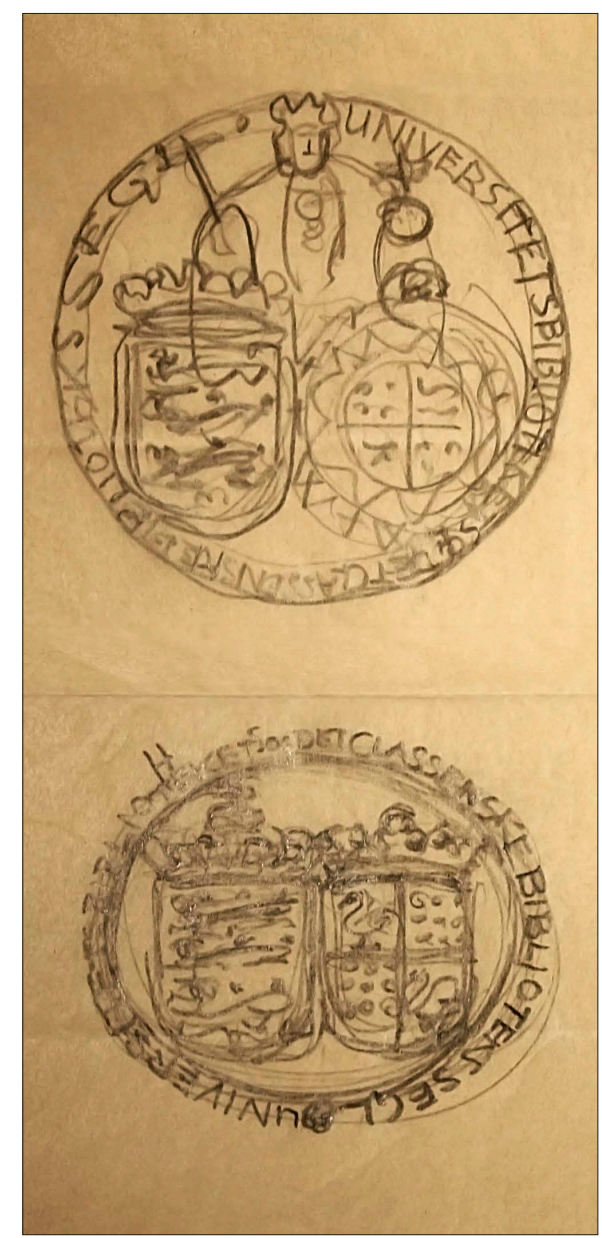

Ill. 4. De forste blyantsskitser, april 1909.

En tredje person, der spillede en væsentlig rolle i forbindelse med logoets tilblivelse, var arkivaren, genealogen og heraldikeren Anders Thiset ${ }^{12}$ (18501917), som, skønt uden akademisk uddannelse, blev arkivar ved Rigsarkivet og som, uden selv at være adelig, grundlagde Danmarks Adels Årbog. Thiset var på det tidspunkt landet mest fremtrædende heraldiker, og han blev lejlighedsvis rådspurgt af offentlige institutioner, ${ }^{13} \mathrm{og}$

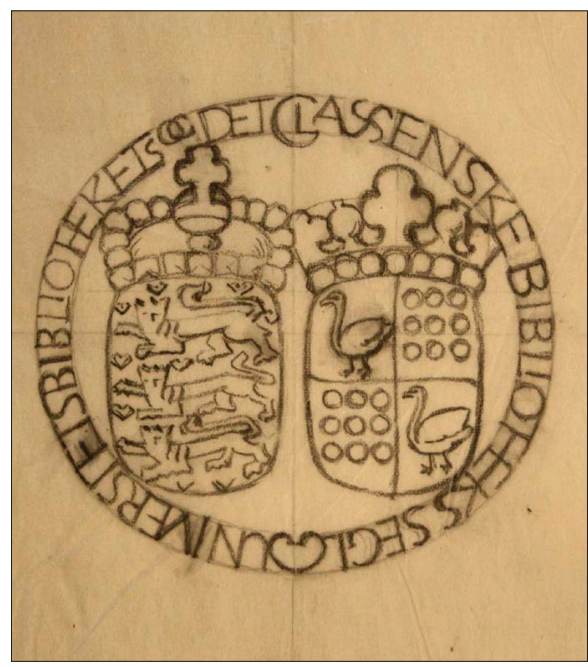

Ill. 5. Viderebearbejdning at en af de forste skitser, 18. oktober 1909.

han kunne afgive responsum-lignende udtalelser.

\section{7 hiset blev på et tidligt tidspunkt konsulteret af Engelhardt. Engel- hardts omfattende arkiv af skitser} m.v., men ikke hans korrespondance, opbevares i Designmuseum Danmark, ${ }^{14}$ og her findes bl.a. et spørgsmål-svar-papir, dateret "Formentligt efteraar 1909", omkring Classens våben. Engelhardt har forberedt mødet med Thiset ved at skrive sine spørgsmål ned på forhånd og så notere svarene med blyant. Spørgsmålene var alle af heraldisk karakter, f.eks. "Er det forsvarligt, at lade Chr. 3 faa 2 Vaaben at vogte over, antydet i hosliggende Blyants udkast?", hvortil Thiset svarede: "Daarlig nok, det er at gjøre lidt for meget væsen af Hr. Classen", eller betydningen af den stjerne, som ligger bag våbenet - stjernen fra ordenstegnet som hvid ridder.

Engelhardt arbejdede videre med den ene af de to skitser fra april, og den 18. 


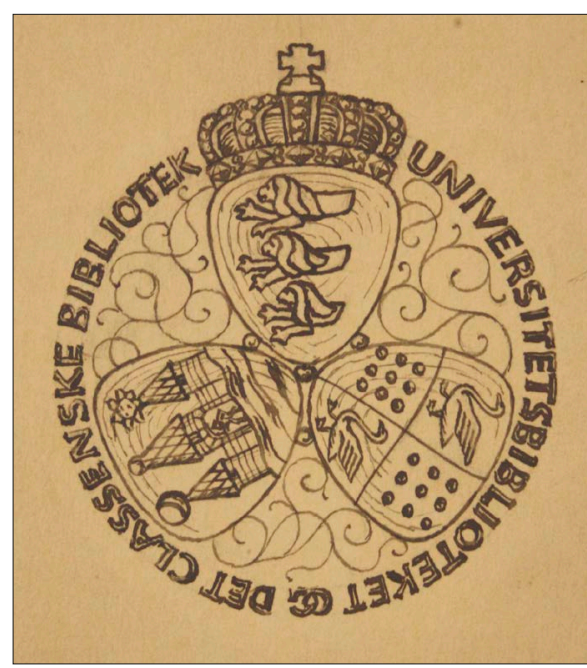

Ill. 6. Ny udformning med tre skjolde. Københavns byvåben er kommet med, august 1912.

oktober kunne han levere en ny skitse, som var langt fastere i stregen (ill. 5). Skitsen må antages at være udarbejdet på baggrund af samtalen med Thiset, det tyder spørgsmål og svar på. Nu går der 11 måneder før næste skitse foreligger, og den er som den tidligere med to våben, nemlig statsvåbenet med løver og hjerter og det Classenske våben. Engelhardts noter på skitsen viser, at Thiset er blevet konsulteret endnu en gang.

Næste skitse (ill. 6) er endnu et år undervejs, og den er radikalt anderledes. $\mathrm{Nu}$ er logoet rundt, og der er tre skjolde, nemlig Universitetet øverst, Classen til højre og København med de tre tårne til venstre.

Sofus Larsen sendte dette udkast til Thiset for at få en udtalelse, men Thiset var ikke tilfreds. Han skrev til indledning: $:^{15}$

"Jeg takker oprigtig for Hr. Overbibliothekarens elskværdige Brev af 2. d. M. og jeg er ingenlunde ufølsom for den Ære, der er viist mig ved Forelæggelsen

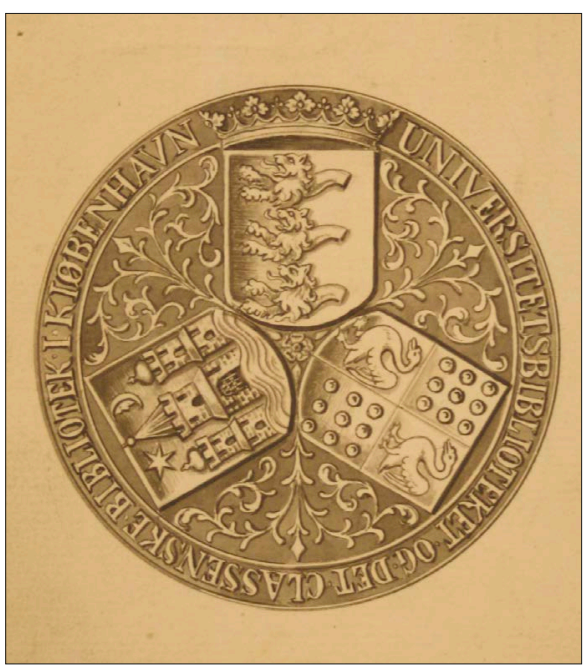

Ill. 7. Thisets forslag, september 1912.

af det herved tilbagefølgende af Arkitekt Engelhardt udførte Forslag til et Segl eller Mærke for Universitetsbibliotheket til min Bedømmelse, og dog kunde jeg have ønsket, at denne Ære var blevet en Anden til del end mig. Jeg vil nemlig uhyre nødig fortrædige Hr. E., der aldrig har gjort mig andet ondt end af og til at øde min Tid paa sikkert meget velmente, men desværre alt andet end vellykkede Forsøg paa at vinde min meget gammeldags Smag for hans yderst moderne Kunst."

Herefter kommer indvendingerne, og de er mange: Skjoldformen med afrundede hjørner hører en kort periode $\mathrm{i}$ middelalderen til; kronen, som er forkert, bør ikke rage helt uden for logoets rand; Thiset påtaler "de ganske uheraldiske Løvefigurer, der synes laante fra et eller andet oldægyptisk eller oldassyrisk Monument", og endelig skriver han, at "Mine øvrige Indvendinger mod Ornamenter og Omskrift skal jeg lade uomtalt de ere netop Smagssager, som der ikke kan 


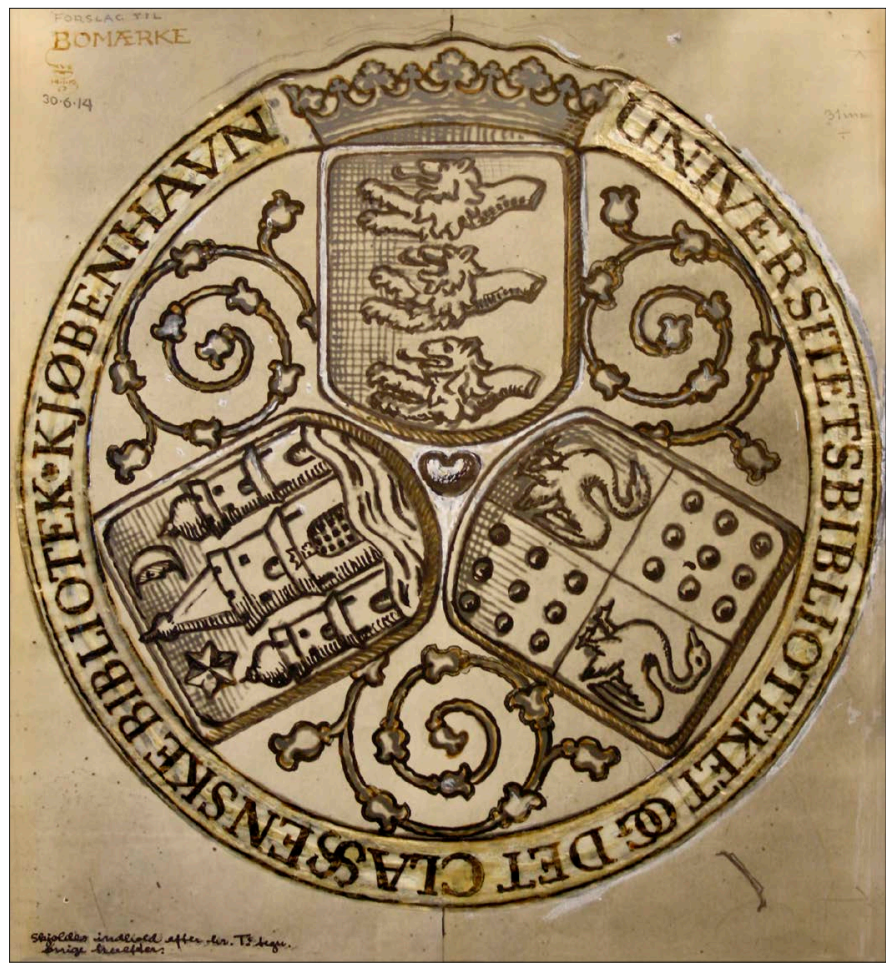

Ill. 8. Engelhardts udkast på grundlag af Thisets tegning. To datoer: 14. januar 1913 og 30. juni 1914.

eller rettere sagt ikke bør diskuteres om.” Men Thiset er en hjælpsom natur, og han vedlægger en tegning med et udkast, "som ganske stilles til Hr. Overbibliothekarens Raadighed" (ill. 7). Han knytter er række bemærkninger til udkastet, herunder en udførlig begrundelse for de tre halve løver i Universitetets våben. Hele Thisets brev er på grund af sin karakter af responsum aftrykt i festskriftet til Universitetsbibliotekets 500 års jubilæum i $1982 .{ }^{16}$

Uden at skrive om det i sit brev, har Thiset spejlvendt de fire felter i det Classenske våben, og denne fejl blev ført videre i den endelige udformning af logoet.

$\mathrm{Nu}$ var der sådan set kun tilbage at færdiggøre udkastet, og det forelå den 30 . juni 1914. Forud var dog gået et arbejde, som også havde involveret "en duelig billedhugger” og Joakim Skovgaard (1856-1933), ${ }^{17}$ professor ved Kunstakademiet og i øvrigt en af Engelhardts lærere. Skovgaard var en af Danmarks kendteste kunstnere; han står bl.a. bag freskerne i Viborg Domkirke og (sammen med Bindesbøll) Dragespringvandet på Rådhuspladsen i København. Engelhardt satte ikke sit lys under en skæppe, ${ }^{18}$ så involveringen af Skovgaard skal snarere end usikkerhed ses som et led i Engelhardts perfektionisme.

Selv denne, den sidste version fra Engelhardts hånd, kan virke løst tegnet (ill. 8). Det var en del af hans metode: "Og med tegningerne fulgte mundtlige instrukser og omstændelige forklaringer til forståelse af mening og baggrunden 


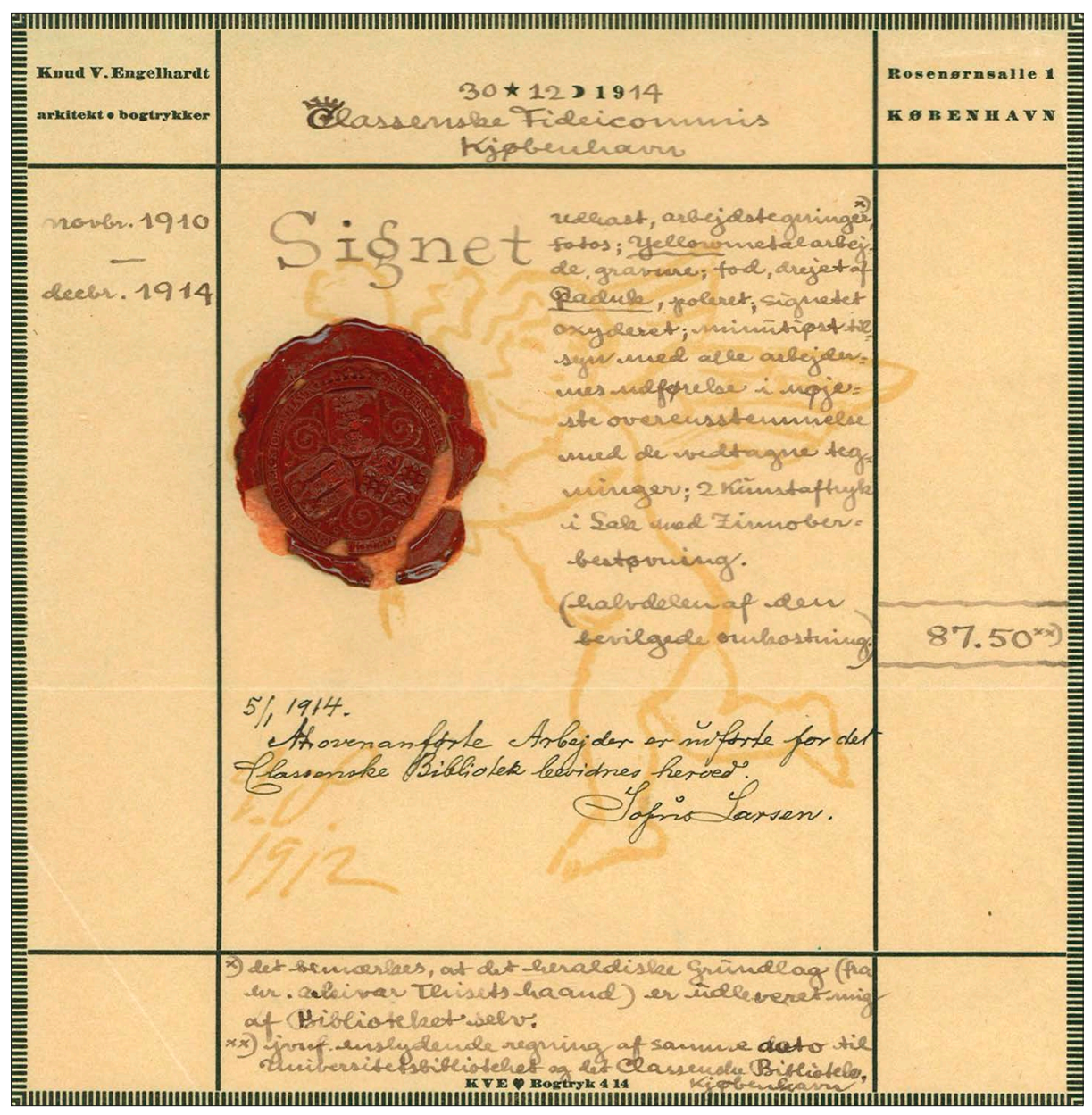

Ill. 9. Engelhardts faktura af 30. december 1914 til Det Classenske Fideicommis med Engelhardts beskrivelse af arbejdet og Sofus Larsens attestation 5. januar 1915.

for løsningen. Hovedformen var det vigtigste, Petitesserne kunne man tale om." ${ }^{19}$ I samme retning peger, hvad Engelhardt skrev til Sofus Larsen den 6. februar 1913 i forbindelse med sit (næsten) endelige forslag:

"Sluttelig anmoder man om indenfor den i udkastene antydede ramme - at have fuld frihed til enkelthedernes behandling, for at der under selve udførelsen paa ethvert punkt kan tages alle fornødne hensyn til stemplernes naturlige tekniske krav. [tegnet blomst] Denne anmodning fremkommer som følge af en forelæggelse af hele problemet for professoren i dekorativ kunst ved Kunstrakademiet, hr. Joachim Skovgaard, da jeg nødig $i$ en saa vigtig sag vil staa helt alene om det rent kunstneriske ansvar. Det er mit haab, 


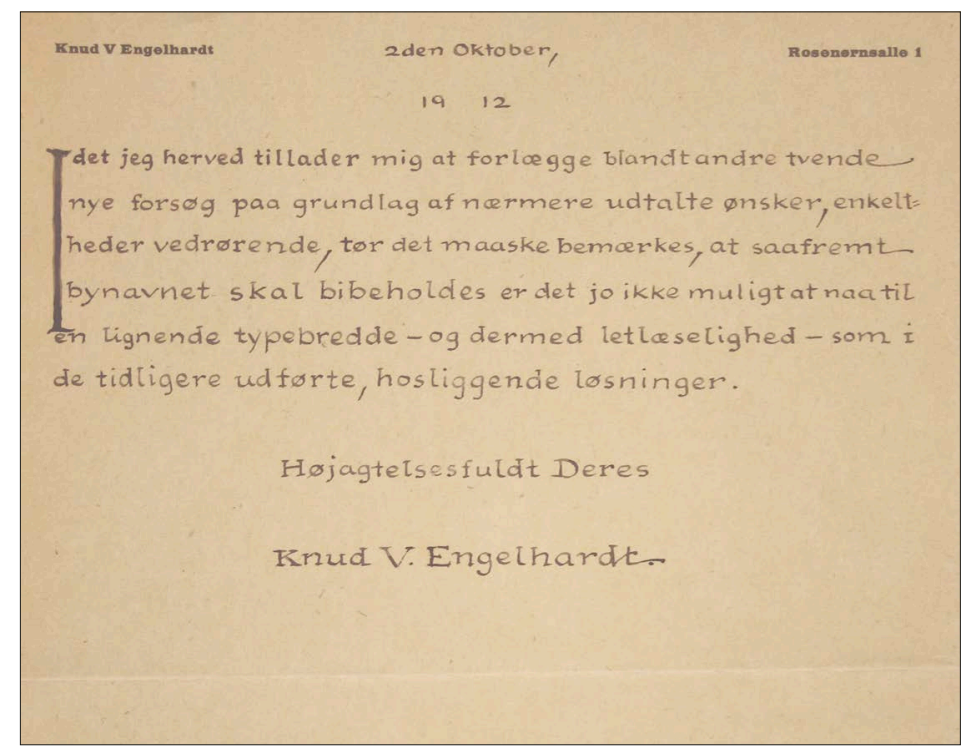

Ill. 10. Brev fra Engelhardt til Sofus Larsen hvor Engelhardt lader 'I' i ordet 'Idet' udgore et veldigt initial, og bvor han skriver med 'trykt' haindskrift. Oktober 1912.

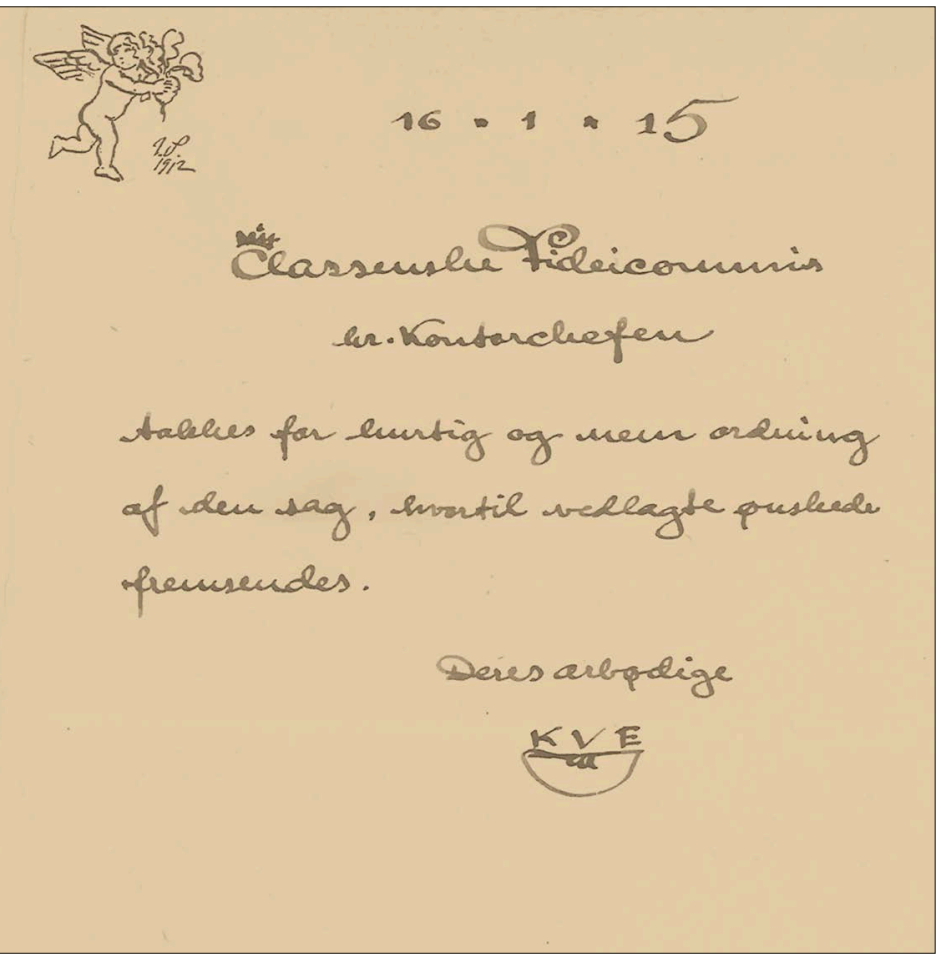

Ill. 11. Engelhardts takkeskrivelse til Fideicommisset for burtig behandling af sagen; her er det hans sedvanlige haindskrift, men forsynet med forskellige krummelurer. Januar 1915. Englen er tegnet af Joakim Skovgaard. ${ }^{25}$ 
at denne professor Skovgaards henstilling maa tjene sagen til god vejledning under dens videre behandling".

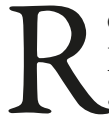
esten var teknik og økonomi. Det tekniske stod Engelhardt selvsagt for. Den 31. oktober sendte han et prøvetryk til Sofus Larsen. Ledsagebrevet afsluttede han sådan: "Saafremt ingen indvendinger fremkommer i de nærmeste dage, antager jeg at kunne aflevere det hele i løbet af en 14 dages tid fra nu af; thi det volder mig vanskeligheder at hidskaffe det særegne papir under de urolige forhold sydpaa." Vendingen "de urolige forhold sydpaa" må nærmest være årtiets underdrivelse. Første Verdenskrig var i fuld gang, og skyttegravskrigen på Vestfronten var allerede låst fast for de næste fire år.

Økonomien klarede Sofus Larsen som antydet $\mathrm{i}$ indledningen ved at skrive til Konsistorium og Det Classenske Fideicommis, som tilbød at betale halvdelen. Det fremgår af arkivet på Corselitze, at direktionen var ægte interesseret i projektet; repræsentanter for direktionen var mere end én gang på besøg på biblioteket, og man accepterede udkastet, selv om man hellere havde set, at Universitetets våben og det Classenske var sidestillede, og at svanerne ikke havde oprejste vinger, men hvilende som i Classens eget våben. I arkivet ligger også et 1912-udkast fra Engelhardts hånd med påskriften: "Forbliver her. Givet mig af Hr. Larsen”.

Engelhardts honorarer var "til tider også efter datidens forhold - formidable og kunne bringe bestyrtelse hos klienter, som måske var blevet rendt på dørene i årevis. De havde kun få forudsætninger for at sætte sig ind i, hvor grundigt arbej- det var udført, .... ${ }^{20}$ Heri kan man se en begrundelse for Engelhardts omhyggelige præcision af, hvad der var udført:

"Udkast, arbejdstegninger, fotos; yellowmetalarbejde, gravure; fod, drejet af Paduk, ${ }^{21}$ poleret; signet oxyderet; minutiøst tilsyn med alle arbejdernes udførelse i nøjeste overensstemmelse med de vedtagne tegninger; 2 kunstaftryk i Lak med Zinnoberbestøvning".

Regningen (ill. 9) er omtrent på dato dateret 100 år før udgivelsen af dette nummer af Magasin fra Det Kongelige Bibliotek, og den lød på $175 \mathrm{kr}$., svarende til ca. $10.000 \mathrm{kr}$. i $2013,{ }^{22}$ eller hvad en faglært arbejder i byerne tjente på knap $61 / 2$ uge $(1$ uge $=48$ timer à 57 øre $){ }^{23}$ Fordi beløbet skulle deles medlem Universitetsbiblioteket og Det Classenske Fideicommis skrev Engelhardt to regninger, hvor den her afbildede stammer fra Fideicommissets arkiv. ${ }^{24}$

Sofus Larsen har øjensynligt satset en del for at få sit logo. Den tidligste skitse er fra april 1909, blot et par måneder efter hans tiltrædelse som overbibliotekar, men det var først i april 1914, han spurgte om tilladelse i Konsistorium og Fideicommisset. Undervejs har han involveret Engelhardt og Thiset - og Engelhardt har på sin side involveret Thiset og Joakim Skovgaard. Alt sammen uden at det kunne vides, om projektet blev til noget. Dog kan der have været mundtlige kontakter, som ikke har sat sig spor i arkiverne.

Samarbejdet mellem Sofus Larsen og Engelhardt fortsatte og resulterede i en rendyrkning af Universitetsbibliotekets tryksager i 1916..$^{25}$ og af Engelhardts arkiv i Designmuseum Danmark ses det, at Engelhardt har arbejdet med sagen så sent som i 1921. 
Engelhardts omhyggelige arbejde med sine projekter er legendarisk, men når man ser korrespondancen omkring logoet, virker det nærmest, som om han også var lidt af et legebarn. På hans brevpapir, som var ret spartansk udstyret, eksperimenterer han med det skriftlige udtryk (ill. 11).

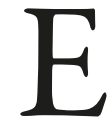

ngelhardts logo fik i første omgang ikke noget langt liv på Universitetsbibliotekets brevpapir. Logoet forsvandt, da den noget mere prosaisk indstillede Svend Dahl blev overbibliotekar i 1925. På Universitetsbibliotekets 2. Afdeling (UB2) blev logoet taget i brug igen i $1976^{26}$ ved hvilken lejlighed det Classenske våben blev vendt rigtigt igen. På UB1 skete det senest i forbindelse med forberedelserne til Universitetsbibliotekets 500 års jubilæum i 1982.

I år 2000 ønskede Danmarks Natur- og Lægevidenskabelige Bibliotek, som biblioteket på Nørre Allé nu hed, at Engelhardts logo blev nyfortolket som led $i$ et nyt designprogram, leveret af firmaet Paramedia. Et udkast blev sendt til Rigsarkivet for godkendelse. Det blev det ikke. ${ }^{27}$ Der var mange indvendinger i stil med dem, Thiset havde haft i 1914: Udformningen af kronen, adskillelsen mellem felterne i det Classenske våben m.v., men den væsentligste anstødssten var dog anvendelsen af Københavns byvåben i logoet. Hvad der havde været uproblematisk i 1914, kunne ikke længere lade sig gøre. Også de halve løver for Universitetet blev påtalt af Rigsarkivets heraldiske konsulent, Nils G. Bartholdy, som anførte, at Thiset havde taget fejl. Helst så Bar-

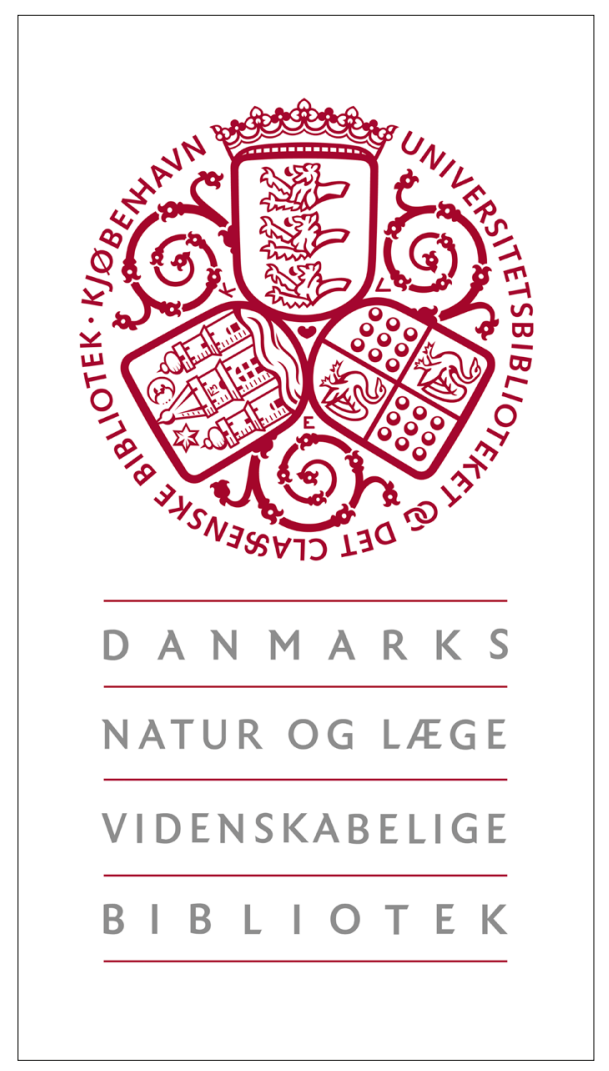

Ill. 12. DNLB's logo med understillet biblioteksnavn. 2002-2005.

tholdy, at der skete en ændring af logoet, så København udgik, men han pegede dog også på en kattelem, nemlig at man bibeholdt det gamle logo uændret, og det blev så løsningen. Logoet blev rentegnet, intet andet (ill. 12). Logoet blev så indtil fusionen med Det Kongelige Bibliotek anvendt enten alene eller sammen med bibliotekets navn under logoet. 


\section{Noter}

1 Pakke 42, 1914, Det Classenske Fideicommis' arkiv på Corselitze; Københavns Universitet, Jnr 1914/11, Rigsarkivet.

2 Torsten Schlichtkrull: "Det Classenske Bibliotek. Samlingens udvikling og videre skæbne", Bibliotekshistorie 8 (2007), s. 5-37.

3 Astrid Paludan-Müller: Generalmajor Classen 1725-1792 (1923), s. 210.

4 "Koustrup, Jørgen: Indkomne breve (1786-1790) 5”, Rigsarkivet.

5 Erik Ellegaard Frederiksen: Knud V. Engelhardt. Arkitekt og bogtrykker 18821931 (1965), s. 68.

6 Ibid., s. 37.

7 Ibid., s. 39.

8 Ibid., s. 17 og 39.

9 Ibid., s. 39.

10 Mail fra kommunearkitekt Christian Olesen, Gentofte Kommune, den 27.2.2014.

11 Ellegaard Frederiksen: Knud V. Engelhardt. Arkitekt og bogtrykker 1882-1931, s. 37.

12 A. Thiset, Dansk biografisk Leksikon, 29.9.2014, <www.denstoredanske.dk/ Dansk_Biografisk_Leksikon/Historie/ Genealog/A._Thiset>.

13 Nils G. Bartholdy: Regulering af dansk officiel heraldik i nutiden, Arkiv 12 (1988), s. 74.

14 Danske Kunstneres Dekorative Tegninger. Knud V. Engelhardts tryksager I; 871-885, Designmuseum Danmark.
15 "KU, Universitetsbiblioteket: Henlagte sager og diverse (1901-1923) 1602-16", Rigsarkivet.

16 Poul Aagaard Christiansen, "Slutvignet om Universitetsbibliotekets mærke. K. V. Engelhardt og A. Thiset ved arbejdsbordet", Bibliotek for Lager 174, Supplement 1 (1982), s. 229-232.

17 "KU, Universitetsbiblioteket: Henlagte sager og diverse (1901-1923) 1602-16", Rigsarkivet

18 Ellegaard Frederiksen, Knud V. Engelbardt. Arkitekt og bogtrykker 1882-1931, s. 17.

19 Ibid., s. 12.

20 Ibid.

21 Dvs. Padauk, en af de fineste møbeltræsorter.

22 Danmarks Statistik. Forbrugerprisindeks, åbnet 22.9.2014, < dst.dk/ $\mathrm{da} /$ Statistik/emner/forbrugerpriser/ forbrugerprisindeks.aspx $>$.

23 Poul Thestrup, Mark og skilling, kroner og ore. Pengeenheder, priser og lonninger i Danmark i 350 ar (1640-1989) (1991), s. 45.

24 Pakke 42.

25 Ellegaard Frederiksen, Knud V. Engelhardt. Arkitekt og bogtrykker 1882-1931, 69.

26 Aagaard Christiansen, Slutvignet om Universitetsbibliotekets mærke. K.V. Engelhardt og A. Thiset ved arbejdsbordet, 230.

27 DNLB's arkiv 1976-2005, 3-30, Det Kongelige Biblioteks arkiv. 


\section{Indkaldelse af ansøgninger til \\ Frimærkehandler og jernbanehistoriker Peer Olav Thomassens Fond}

\section{Ansøgningsfrist: I. april 2015}

Fonden, som er stiftet i 1992, har formålet "Videreførsel af forskningen i fortrinsvis dansk trafik- og kommunikationshistorie" og yder støtte til:

a. Anskaffelse af relevant materiale, herunder til den fornødne bevaring, registrering, katalogisering, indbinding, konservering mv. af det indgåede materiale.

b. Udarbejdelse af publikationer, først og fremmest trykomkostninger.

c. Studie- og forskningsudgifter, herunder rejsetilskud.

d. Tilskud til afholdelse af udstillinger, seminarer, kongresser m.v.

Ad a: Støtte til opbygning af private bogsamlinger falder uden for formålet.

Ad c: Da fondens midler er af forholdsvis beskeden størrelse, vil det ikke være muligt at yde effektiv støtte til forskning inden for de i formålsparagraffen nævnte områder i form af løn.

Af hensyn til ekspedition af imødekomne ansøgninger, skal disse indeholde oplysning om modtagerens adresse og personnummer. Hvis ansøgeren er en juridisk person, skal man i ansøgningen oplyse CVR-nummer.

Ansøgning vedlagt curriculum vitae, eventuel publikationsliste samt anbefalinger stiles til direktør Erland Kolding Nielsen og sendes til:

\section{Det Kongelige Bibliotek}

elektronisk: kb@kb.dk

eller fysisk: Postboks 2149

1016 København K

så den er biblioteket i hænde senest 1. april 2015 med morgenposten / kl. 12:00.

Uddelingen forventes at finde sted i maj-juni 2015. 